\title{
Mapping of the Research Output in Food Economics: A Scientometrics View of the Scopus Database
}

\author{
R.Sebastiyan $^{1 *}$, V.Rameshbabu ${ }^{2}$, T.M.Surulinathi ${ }^{3}$ \\ ${ }^{1}$ Bharathidasan University, Tiruchirappalli, India \\ ,${ }^{2}$ TBML College, Porayar, India \\ ${ }^{3}$ Bharathidasan University, Tiruchirappalli, India \\ 1viruthiruseba@gmail.com,Tel.:91+9786414100 \\ 2veerameshbabu@gmail.com \\ ${ }^{3}$ surulinathi@gmail.com
}

\begin{abstract}
Since food is considered important in the world, the current study analyzed the characteristics of scientific publications based on several subtle indicators of scientometrics in the field of food economics for strengthening public health in the future. Accordingly, a total of 26306 publications from 1915 to 2021 are evaluated based on the Scopus database with the help of scientific tools such as Hitcite, Biblioshiny and VoS viewer. The results show that the resourcefulness experts are identified in terms of their publication only, that namely Drewnowski, Kesselheim. On the other hand, the author Popkini is considered as the key author rather than the above-said authors in terms of global citations. The similarity in the above context is that all the topmost authors belong to the USA. More importantly, the summary of citations in total publication output is revealed that a single paper is recorded the range of citations between 1042-2766, the 500 citations are recorded from the 64 papers, and 844 papers accounted with more than 100 citations.
\end{abstract}

Keywords: Food, Economics, Scientometrics, Publication, Author, Output, Citation

\section{Prologue}

The ideal concept of Food and Economics that are the most an important literature aspects be reviewed and resolved in terms of its current trend activities to maintain the sustainable resources in the world [20]. The demanding of Food has been wobbling during the COVID19, as, consequently, 132 million people have suffered from hungry as per report of Alders \& Dar [16], and food commodity price is also raised by restriction of travelling between state to state and region to region due to global lockdown [19].

In the 21 st century, seeing influence intelligence as a sign of scientific development, it has become very simple. In today's scenario, we have a huge development plan to be executed if we focus on it as micro-level reviewing in the scientific literature in terms of a systematic manner[1], [6]. If looking such like that, the Bibliometrics or scientometrics that sub-field of library \& information science is helping to frame the research performance so as to identify the key subject experts [4], [13]. Scientometrics analysis is not only to identify the importance in the research domain, but it also helps in making decision policy that $[10,[11]$ through publication impact as well as the citation impact supports in framing the research proposals for the country development [21].

As such reflecting of citation impact, the resourcefulness authors through micro-level, and country \& institution under macro-level would be identified. Furthermore, scientometrics can promote the academic culture across the world by research contributions [5]. Generally, many 
successful projects, particularly in the most developed countries executed through such kind of scientific evaluation approach, namely the H - Index and Impact Factor on channel of publication. Therefore, extracting the quantity as well as quality in research contribution can be filtered by adopting scientometrics tools on concerned the filed in publication output. [2].

Since the new global coronavirus outbreak (COVID-19), many people could not balance their vitamin healthy food due to continued lockdown, causing poverty leads to raise death day by day [22]. In this situation, the resolutions to be needed to frame the new policy towards the county development, particularly in public health that to be monitored in terms of research publication output of experts and Research scholars as well as Post Graduate scholars [15].

In this circumstance, the experts' special attention to public health likely will increase in further development. Concentrating the food loss and waste in the present scenario is an important one in curtaining the production cost and maintaining the better environmental sustainability [14]. Moreover the food loss leads to make heavy price laying on agricultural commodities and decrease in quantity as well as quality between supplier and end user.

As per interpretation given by Gonzalez-Alcaide, [7] on their earlier publications, given the disease burden associated with Chagas cardiomyopathy, a specific analysis of research publications and collaboration networks in this area are warranted to build on the more general bibliometric studies of Chagas disease [11]. Increased knowledge of research in this pathology can help to foster the global collaborations and other research initiatives among endemic countries that nevertheless may have relatively little scientific development of the topic. Moreover, this type of study is useful for the research community, clarifying the main lines of research that are being developed with regard to the diagnostic methods and treatments for the disease.

Therefore, the present study aims to evaluate scientific literature output according to different situation in term of Microanalysis on subject experts, impact journal, Collaboration between countries, citation metrics, visualizing and mapping and the topic addressed [11].

\section{Objectives}

The main purpose of this study is that to ascertain the resourcefulness experts from their publications by reflecting their inputs on public health issues from the current research domain of Food economics. The following highlights to be focused by using scientometrics tools: 1.Who are the most significant contributor in Food Economics? 2. Which organization is on the top position in producing the highly impact peer reviewed journal? and 3. Which keyword is playing frequently among the experts.

\section{Material and Mechanism}

\section{Framing the Research Area}

Since this study is closely associated with bibliometric cum scientometrics analysis method, the suitable bibliographical database information is coined and decided to be gathered from the scientific literature under the subject of "Food" and "Economics".

\section{Identification of Database Pool}


In the current study, the SCOPUS is considered for the retrieving the dataset as it is an internationally accessible database and it is an apt one in the present scenario. The present study has identified the all documents indexed in the SCOPUS according to the descriptor of Food Economics and then restricted the results to the "article" and "review" over the 85 years (1935-2021, Jan 15th). In the spite of publication output in many channels, the article and review are the main document type reference that is shown and interpreted as in table 1 as well as figure 1, which is subjected to evaluation based on the research and development activities on the Microanalysis by author, journal, organization, country and its citations.

Table 1.Channel wise Publication

\begin{tabular}{|l|c|}
\hline \multicolumn{1}{|c|}{ Publication Media } & Output \\
\hline Article & 18823 \\
\hline Review & 2685 \\
\hline Conference Paper & 1706 \\
\hline Note & 988 \\
\hline Book Chapter & 549 \\
\hline Editorial & 472 \\
\hline Short Survey & 376 \\
\hline Letter & 319 \\
\hline Book & 300 \\
\hline Conference Review & 59 \\
\hline Erratum & 20 \\
\hline Business Article & 1 \\
\hline Data Paper & 1 \\
\hline Report & 1 \\
\hline Retracted & 1 \\
\hline Undefined & 5 \\
\hline & 26306 \\
\hline
\end{tabular}

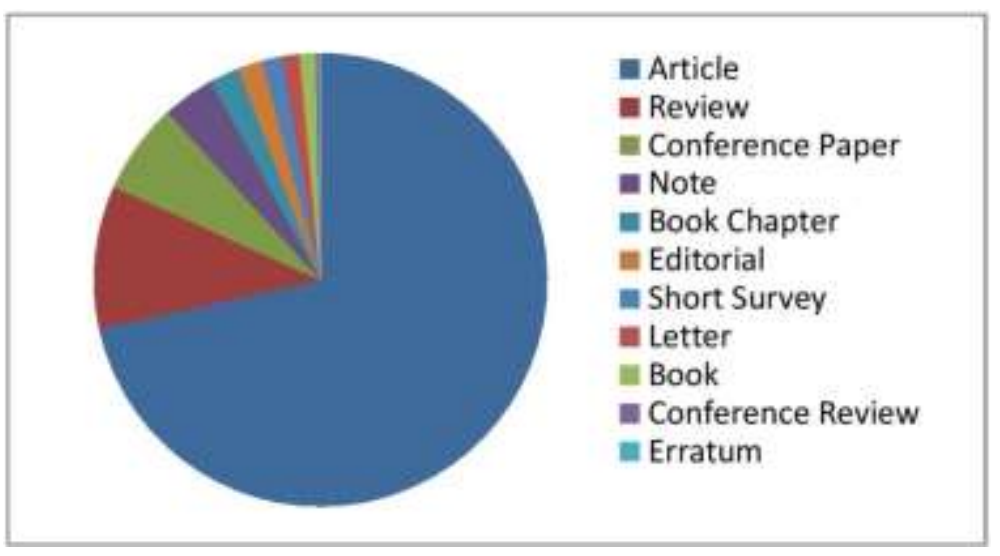

Figure 1.Channel wise Publication

\section{Mechanism}

The collection of bibliographical dataset is measured with the help of Microsoft Excel after downloading and the same is highlighted by applying in the tabular and graph representation respectively in the different situation, according to necessity of emerging trends with availability of modern research tools such as Hitcite, Biblioshiny and VoS viewer for understanding the performing the research systematically.

\section{Overview of Publication}

In order to design the research impact in this research domain, the following findings are revealed in the total 26306 publications, 5824 documents are pertaining open access and the remaining 202482 in the subscription base. The summary of citation is that 1 papers are recorded the range of citations between 1042-2766, the 500 citations are recorded from the 64 papers and 844 papers with more than 100 citations. 


\section{Data Analysis and Interpretation}

The total research contribution has been tabulated from 1915 to 2021 in term of yearly output as per table 2.Because of due to the length of tabulation, a cumulative research output of 26306 is analyzed based on the 10 years inclusive class interval except 20172021. Throughout the 85 years, the topmost research contribution is recorded at $43 \%$ in 2007 2016 alone, which is also highlighted in figure 2. The rest of the period seems that low level of contribution than aforementioned. However, this is gradually increased and from 19771986 the publication output seems that it is double time increased than the previous period up to $1007-2006$.

It is noteworthy to understand that the awareness about publication among world experts is not much more concentrated in their healthy feeling. In addition to that, the current analysis came to understand that the reason for the meager output might be either availability of nature, of healthy food or non-availability of proper media for publication.

Table 2. Period wise Research Output

\begin{tabular}{|c|c|r|}
\hline Duration & \% & Output \\
\hline $1915-1937$ & 0.05 & 14 \\
\hline $1938-1956$ & 0.08 & 22 \\
\hline $1957-1966$ & 0.3 & 81 \\
\hline $1967-1976$ & 2 & 553 \\
\hline $1977-1986$ & 5 & 1373 \\
\hline $1987-1996$ & 8 & 2131 \\
\hline $1997-2006$ & 16 & 4205 \\
\hline $2007-2016$ & 43 & 11298 \\
\hline $2017-2021$ & 25 & 6629 \\
\hline & Total & $\mathbf{2 6 3 0 6}$ \\
\hline
\end{tabular}

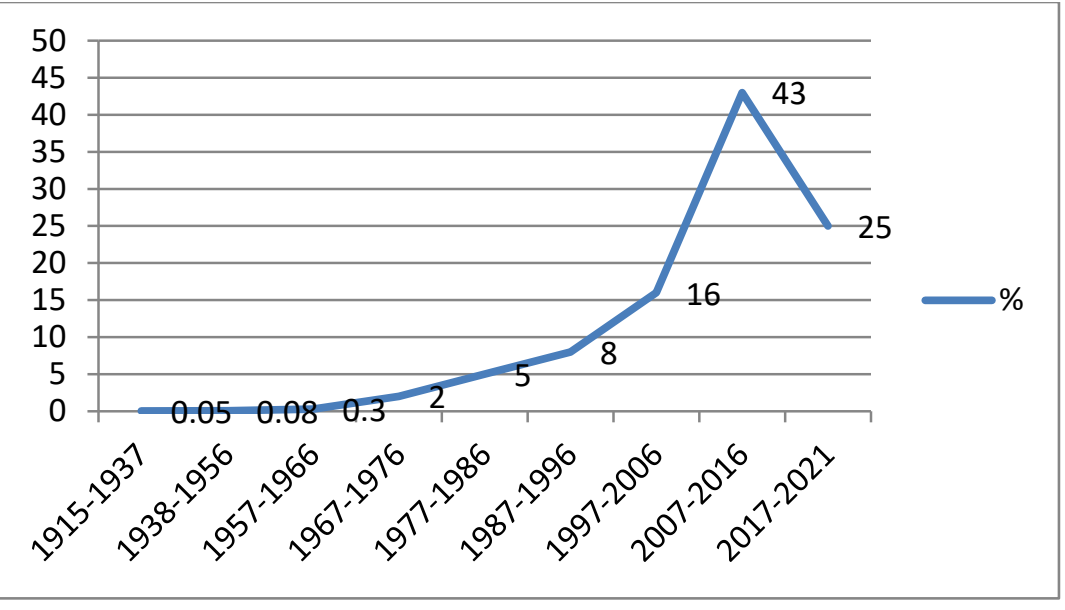

Figure 2.Period wise Output

\section{Identification of Keywords wise Output}

Default keywords are listed in terms of availability of publication records as shown in the table 3.The total 26306 data collections are scattered through many keywords that is coined by research experts in their articles, which leads to understanding and retrieve the relevant information about particular types of earlier document[8], whilst reduces the traffic with save the time. In that respect, not only consider the following keyword "Economics" (17006), "Human" (10429) and "Article" (10184) are the major identification of keywords, but the close relationship words pertaining current study are also identified.

Despite the receipting of majority publication that is differed from technical terminology keywords, such as Human (10429), Article (10181), Humans (8975) and United States (5424) are scanned as per the circumstances. As even though, all the keywords are going to thoroughly filtering under the title each publication according to the current study of Food Economics to make them clarity.

Table 3. Article's Keywords wise Output 


\begin{tabular}{|c|c|c|c|}
\hline Keyword & Records & Keyword & Records \\
\hline Economics & 17006 & Health Economics & 797 \\
\hline Human & 10429 & China & 783 \\
\hline Article & 10184 & Metabolism & 780 \\
\hline Humans & 8975 & Economic Aspect & 777 \\
\hline United States & 5424 & Statistics & 775 \\
\hline Female & 3961 & United Kingdom & 762 \\
\hline Food Supply & 3610 & Fruit & 755 \\
\hline Catering Service & 3274 & Health Promotion & 753 \\
\hline Male & 3202 & Animalia & 748 \\
\hline Food And Drug Administration & 2944 & History & 739 \\
\hline Animal & 2861 & Analysis & 738 \\
\hline Animals & 2854 & Sustainability & 737 \\
\hline Priority Journal & 2820 & Meat & 712 \\
\hline Agriculture & 2515 & Food Handling & 694 \\
\hline Adult & 2356 & Land Use & 693 \\
\hline Food & 1963 & Economic Development & 689 \\
\hline Review & 1916 & Questionnaire & 688 \\
\hline Diet & 1846 & Major Clinical Study & 686 \\
\hline $\begin{array}{l}\text { United States Food And Drug } \\
\text { Administration }\end{array}$ & 1826 & Vegetable & 686 \\
\hline Socioeconomics & 1812 & Population & 677 \\
\hline Food Industry & 1790 & Risk Assessment & 674 \\
\hline Methodology & 1671 & $\begin{array}{l}\text { Growth, Development And } \\
\text { Aging }\end{array}$ & 673 \\
\hline Socioeconomic Factors & 1614 & Food Preference & 666 \\
\hline Procedures & 1558 & Food Safety & 662 \\
\hline Nutrition & 1542 & Preschool Child & 662 \\
\hline Organization And Management & 1463 & Cross-sectional Study & 661 \\
\hline Commerce & 1455 & Food Contamination & 658 \\
\hline Controlled Study & 1455 & Child, Preschool & 657 \\
\hline Developing Countries & 1430 & Infant & 651 \\
\hline Child & 1388 & Population Dynamics & 648 \\
\hline Cost Benefit Analysis & 1387 & $\begin{array}{l}\text { Legislation And } \\
\text { Jurisprudence }\end{array}$ & 645 \\
\hline Cost & 1384 & Psychological Aspect & 631 \\
\hline Poverty & 1358 & Cross-Sectional Studies & 625 \\
\hline Middle Aged & 1348 & Europe & 625 \\
\hline Food Security & 1346 & Public Policy & 625 \\
\hline Standard & 1339 & Health Service & 620 \\
\hline Commercial Phenomena & 1325 & Research & 620 \\
\hline Developing Country & 1317 & Food Services & 619 \\
\hline
\end{tabular}




\begin{tabular}{|c|c|c|c|}
\hline Legal Aspect & 1310 & Cost Control & 617 \\
\hline Health Care Policy & 1283 & Africa & 614 \\
\hline Nonhuman & 1276 & $\begin{array}{l}\text { Cost Effectiveness } \\
\text { Analysis }\end{array}$ & 614 \\
\hline Financial Management & 1223 & Food Service, Hospital & 609 \\
\hline Adolescent & 1217 & Health Care Delivery & 603 \\
\hline Health Care Cost & 1214 & Standards & 601 \\
\hline Environmental Protection & 1208 & Clinical Trial & 598 \\
\hline Drug Industry & 1207 & International Cooperation & 596 \\
\hline Public Health & 1136 & Hospital Food Service & 594 \\
\hline Government & 1129 & Nutritional Value & 590 \\
\hline Chemistry & 1111 & Genetics & 588 \\
\hline Comparative Study & 1111 & Consumer & 585 \\
\hline Sustainable Development & 1104 & Food Preferences & 577 \\
\hline Education & 1087 & Agricultural Economics & 576 \\
\hline Costs And Cost Analysis & 1055 & Risk Factor & 576 \\
\hline Decision Making & 1047 & Nutrition Policy & 574 \\
\hline Obesity & 1037 & Demographic Factors & 565 \\
\hline Aged & 1024 & Environmental Impact & 561 \\
\hline Drug Approval & 1024 & Prevalence & 558 \\
\hline Demography & 1007 & Rural Population & 554 \\
\hline Drug Cost & 1007 & Biotechnology & 551 \\
\hline Animal Food & 996 & Caloric Intake & 548 \\
\hline Cost-Benefit Analysis & 992 & Costs & 545 \\
\hline Health & 992 & Asia & 536 \\
\hline Conservation Of Natural Resources & 991 & Family Size & 530 \\
\hline Physiology & 983 & Family Characteristics & 529 \\
\hline Policy & 977 & Food Processing & 529 \\
\hline Economic Factors & 955 & Politics & 524 \\
\hline Feeding Behavior & 936 & Mortality & 523 \\
\hline Industrial Economics & 904 & Practice Guideline & 523 \\
\hline Income & 896 & India & 519 \\
\hline Marketing & 896 & Psychology & 518 \\
\hline Climate Change & 875 & Information Processing & 517 \\
\hline Food Intake & 870 & Crop & 513 \\
\hline Environment & 863 & Time Factors & 513 \\
\hline Note & 861 & Food Production & 512 \\
\hline Cattle & 859 & Vegetables & 508 \\
\hline Statistics And Numerical Data & 848 & Health Care Planning & 506 \\
\hline Young Adult & 816 & Milk & 505 \\
\hline Animal Feed & 815 & Drug Costs & 503 \\
\hline Environmental Economics & 804 & Microbiology & 500 \\
\hline
\end{tabular}


Ethnology

$801 \quad$ Food Quality

\section{Geographical Research Contributions}

The country wise research performance is depicted in the table 4.The top listed 42 out of 160 countries are ranked in terms of their output, in such way, USA (8763) followed by UK (2248), China (1223, Canada (1166) and Australia (1121) are the highest publication. The most rest of the country is having the blow thousands level of research output. In which, India is the 6th placed among the top performances countries and 51 countries have had single digit in their total publication output as from 5 to 2 respectively. This analysis seems that the USA is a predominated in the publication of research activities rather than other countries.

Table 4. Geographical wise Research Publications

\begin{tabular}{|l|c|l|c|}
\hline \multicolumn{1}{|c|}{ Country } & Output & \multicolumn{1}{c|}{ Country } & Output \\
\hline United States & 8763 & Mexico & 227 \\
\hline United Kingdom & 2248 & Indonesia & 218 \\
\hline China & 1223 & Austria & 202 \\
\hline Canada & 1166 & Russian Federation & 202 \\
\hline Australia & 1121 & Nigeria & 192 \\
\hline Germany & 897 & South Korea & 189 \\
\hline Italy & 816 & Ireland & 181 \\
\hline India & 804 & Malaysia & 176 \\
\hline France & 775 & Thailand & 165 \\
\hline Netherlands & 724 & Finland & 163 \\
\hline Spain & 581 & Poland & 156 \\
\hline Brazil & 443 & Czech Republic & 154 \\
\hline Sweden & 424 & Greece & 151 \\
\hline South Africa & 381 & Taiwan & 143 \\
\hline Belgium & 347 & Turkey & 143 \\
\hline Japan & 340 & Pakistan & 139 \\
\hline Switzerland & 340 & Iran & 133 \\
\hline New Zealand & 300 & Portugal & 131 \\
\hline Denmark & 297 & Ethiopia & 121 \\
\hline Norway & 274 & Hungary & 112 \\
\hline Kenya & 243 & Bangladesh & 109 \\
\hline
\end{tabular}

\section{Top Author Contributions}


Figure 3 illustrates the top authors' performance has been exhibited from the different mindset aspects of them. It is found that a very interesting observation in terms of author performance that the Drewnowski from University of Washington in USA, Kesselheim from Brishton \& Women's Hospital in USA are considered as most countable publications on the current subject of Food Economics rather than other experts. Whilst, Popkini from University of North Carolina in USA who is going to be considered as an unparalleled expert and resourcefulness author rather than others through not only his citation impact by 56821 but also his h-Index is accounted with 126 from just 47 publications as placing in top while comparing others as shown in figure 6.

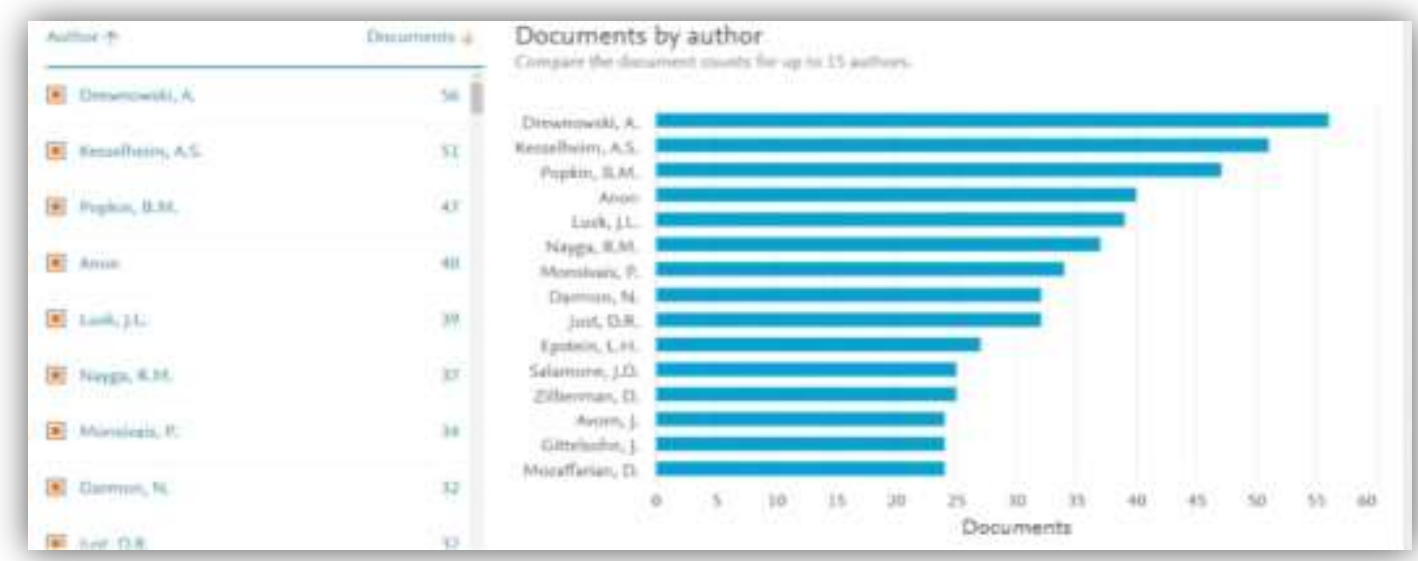

Figure 3.Author wise Publication Output

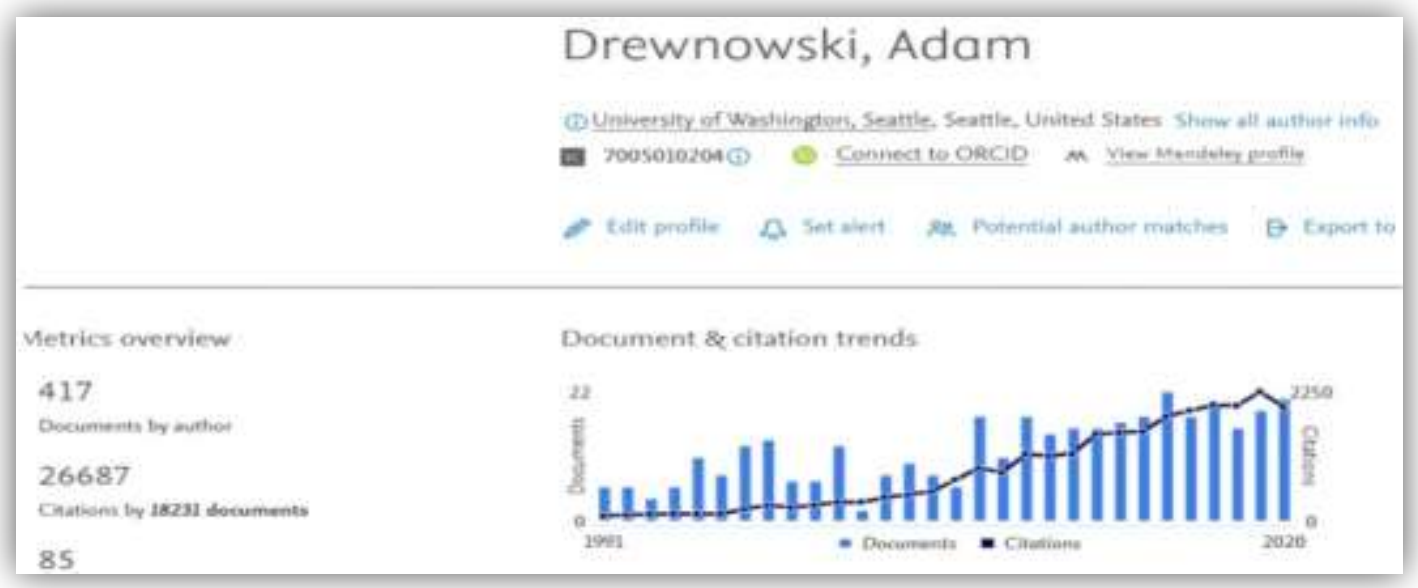

Figure 4-Citation Impact on Author Publication 


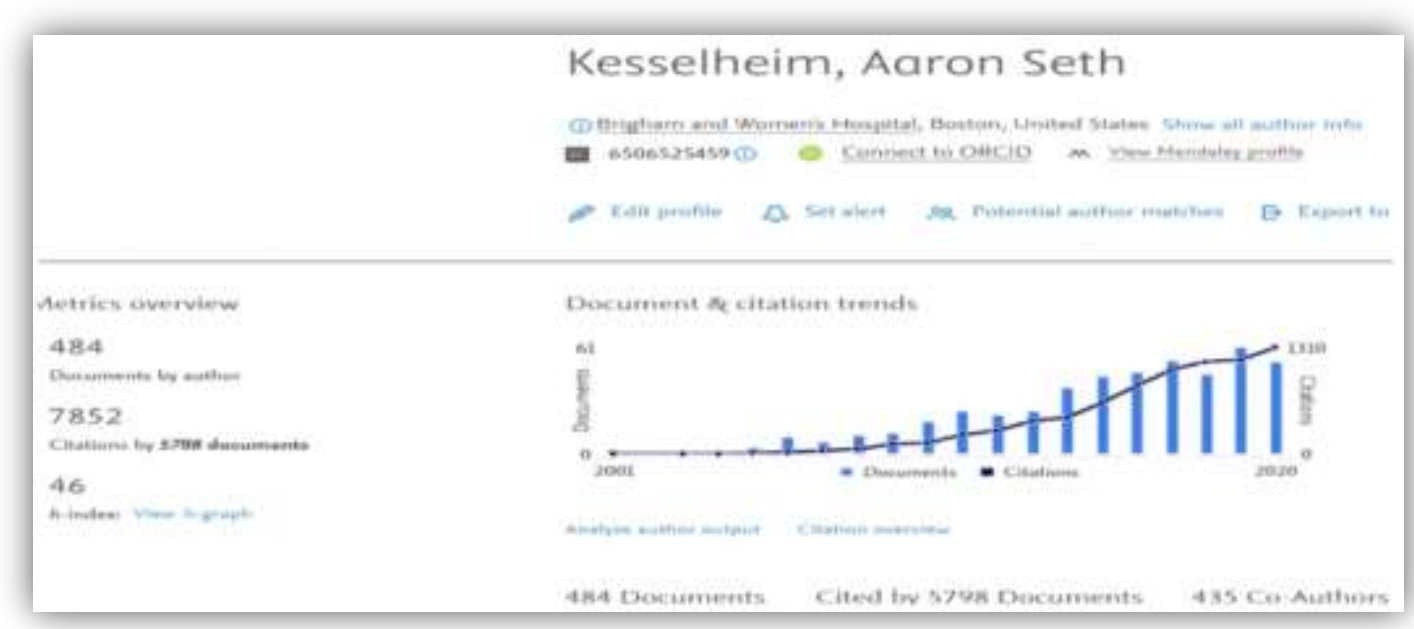

Figure 5.Citation Impact on Author Publication

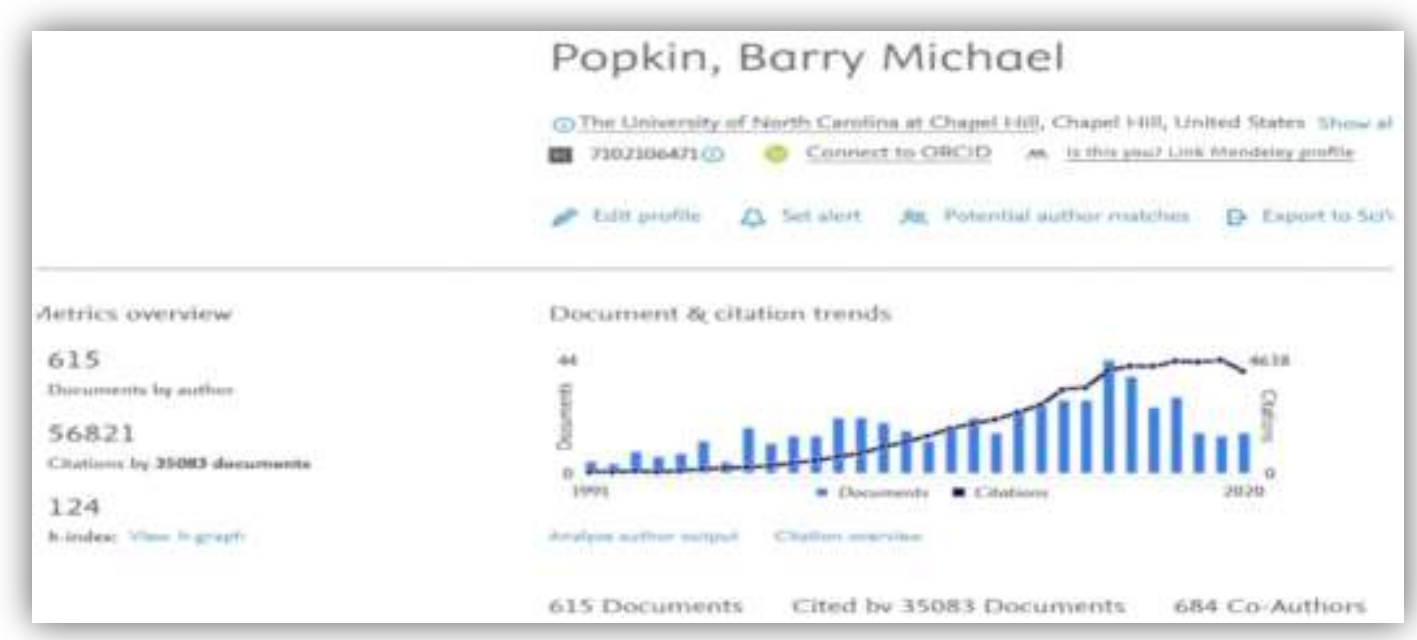

Figure 6.Citation Impact on Author Publication

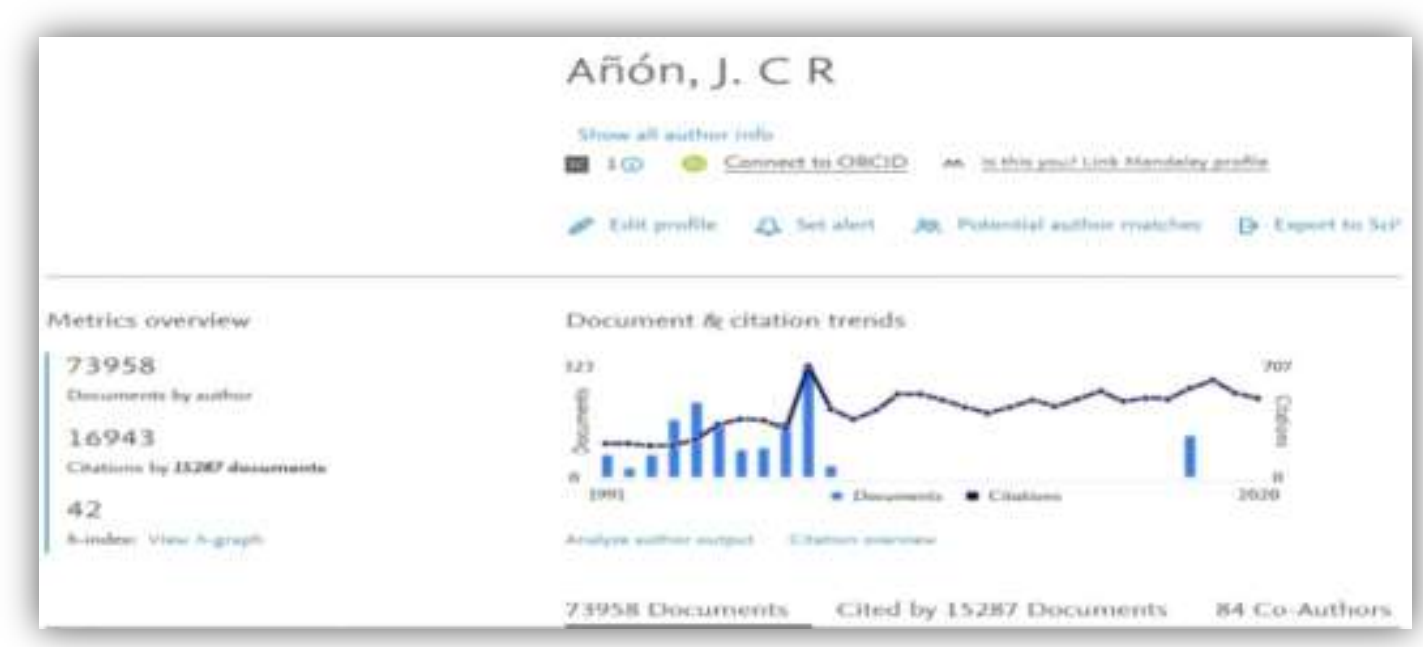

Figure 7.Citation Impact on Author Publication 


\section{Journal wise Publications}

The publication of research articles through the world leading publication group has been identified in the table 5, where the topmost journals are position stopped in terms of total publication about the Food Economics since1936.In which them, American Journal of Agricultural Economics (349), Public Health Nutrition (319) and (300) are seem to be on a large scale of publication output.

Between 200-300, publications are namely that Nature, Journal of The American Dietetic Association and Journal of Dairy Science in the second largest level publication contribution group. The other beautiful finding attraction result to others from the current analysis is that the "Nature" that journal group has had a 51 cite score that is highlighted for the value of the world citation influences through the graphical representation than others publication impact as shown in figure 11.

\section{Table 5.Journal wise Research Publications}

\begin{tabular}{|l|c|}
\hline \multicolumn{1}{|c|}{ Source Title } & Publications \\
\hline American Journal Of Agricultural Economics & 349 \\
\hline Public Health Nutrition & 319 \\
\hline Plos One & 300 \\
\hline Nature & 262 \\
\hline Journal Of The American Dietetic Association & 217 \\
\hline Journal Of Dairy Science & 210 \\
\hline Journal Of Agricultural Economics & 174 \\
\hline Journal Of The Science Of Food And Agriculture & 156 \\
\hline Science & 150 \\
\hline Iop Conference Series Earth And Environmental Science & 140 \\
\hline Appetite & 136 \\
\hline European Review Of Agricultural Economics & 136 \\
\hline Journal Of Animal Science & 136 \\
\hline Science Of The Total Environment & 130 \\
\hline Food Policy & 128 \\
\hline Journal Of Cleaner Production & 127 \\
\hline Food Management & 125 \\
\hline Tropical Animal Health And Production & 121 \\
\hline Ecological Economics & 118 \\
\hline Sustainability Switzerland & 117 \\
\hline Journal Of Food Science & 110 \\
\hline BMC Public Health & 106 \\
\hline Canadian Journal Of Agricultural Economics & 106 \\
\hline Eurochoices & 103 \\
\hline Applied Economic Perspectives And Policy & 101 \\
\hline & \\
\hline & \\
\hline
\end{tabular}




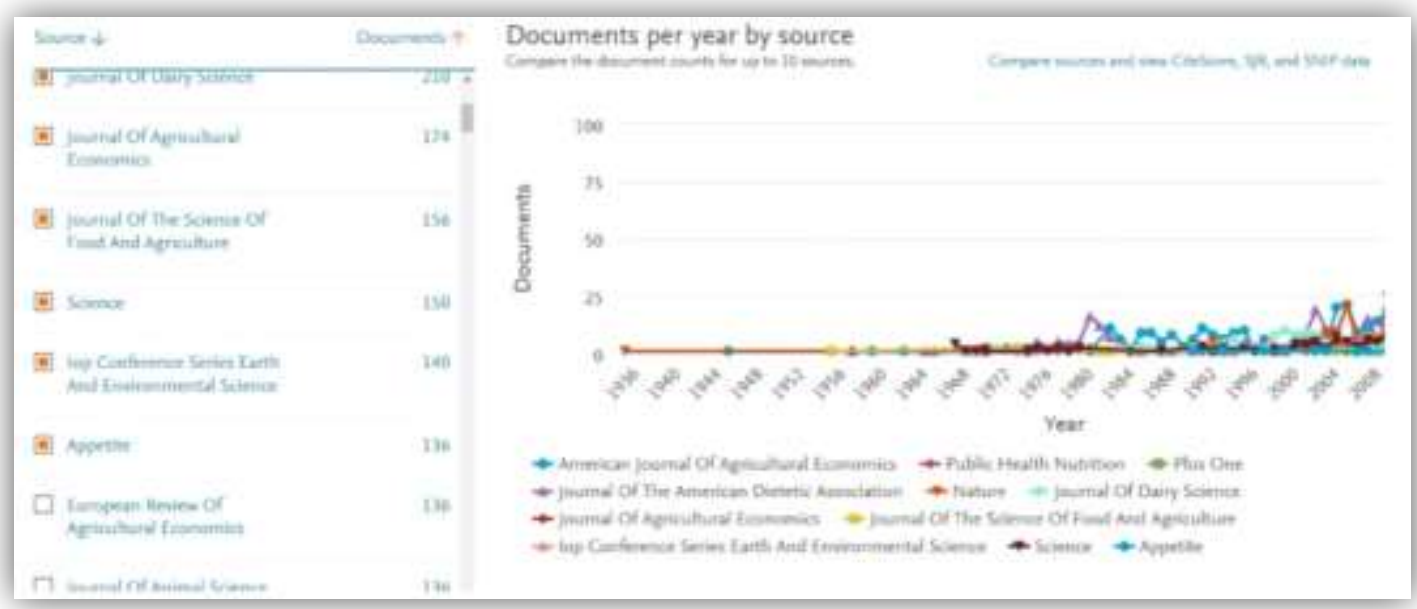

Figure 8.TopJournal wise Publications

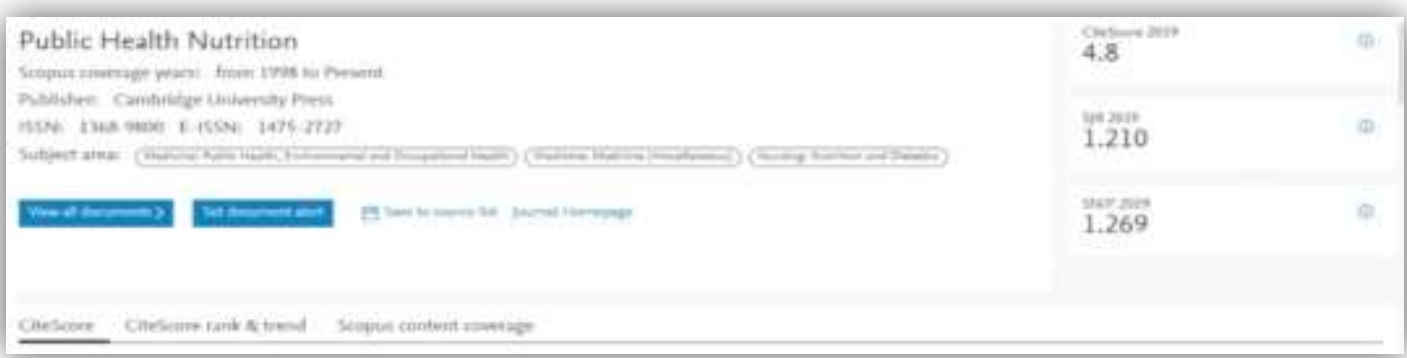

Figure 9.Impact of Journal Publication

\section{PLOS ONE}

apmatem 0

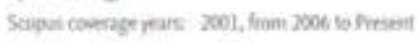

Pultiblet Pubic Library of Sciesce

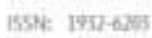

Subiect ave

Wadsanes

5.2
yisens
1.023
1.205

Figure 10. Impact of Journal Publication

\section{Nature}

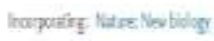

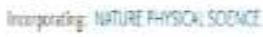

Sropus coverge years: from $186 \%$ to Present

Pubtsher: Springer Nature

ISSN: $028-0836$ E-155N: $1476-4687$

Subjectarex: Witasopirof

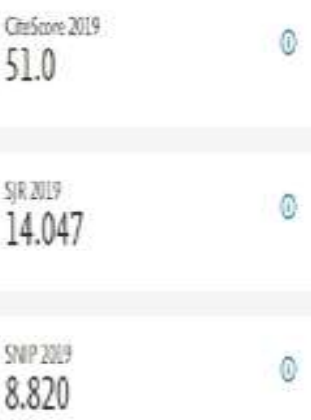

Figure 11. Impact of Journal Publication 


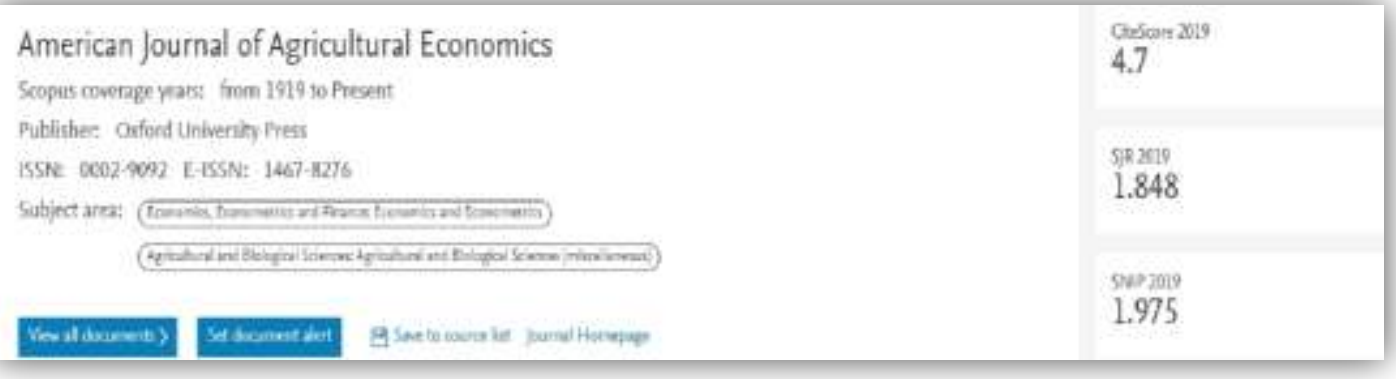

Figure 12. Impact of Journal Publication

\section{Subject wise Research Publications}

The subject wise publication has been measured as shown table 4.The major subjects are arranged based on the publication output such as Medicine (9615) is the highest position followed by Agricultural and Biological Science (7015), Environmental Science (7073), Social Science (3568) and the rest of the subject field has had below 3 thousand. This analysis seems that most of the experts have represented the medicine related ideas and suggestions that reflected as a top resolutions in Medicine.

\section{Funding Sponsors}

Generally, in research and development activities, sponsoring body is taking significant contribution part in particularly assisting the financial support, which is reflected clearly, in the figure 8 .The 15 more sponsoring organizations are identified as high based on the publication output. Among them, National Institute of Health and National Natural Science Foundation of China are the remarkably supporting in producing more than 200 research publications in the current research area of Food Economics.

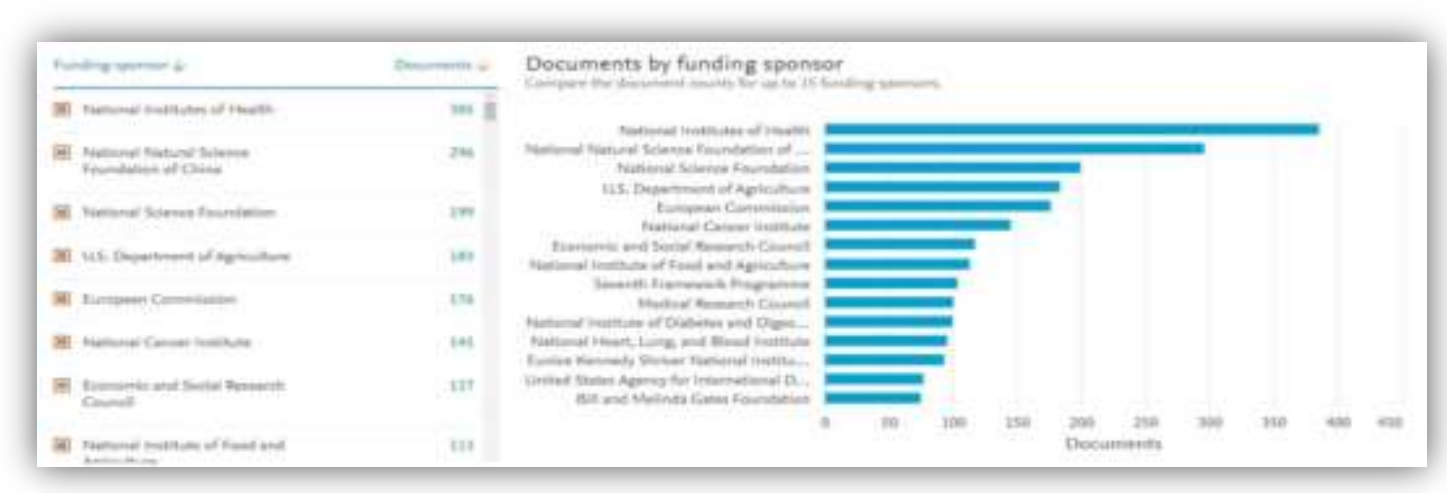

Figure 13.Sponsoring Body

\section{Institutional wise Publication Output}

The research publication output of the Institution is demonstrated as shown in figure 9. The top performance in publication research articles only is listed. Washington University \& Research (322) is highly dominated comparison with other Institutions. Cornell University, United State Department of Agriculture, Harvard Medical School, and University of California share more than 200 research publications, Davis.4 different Institutions are 
recognized by more than 180 research publications that seem as least contribution in this concerned. It is beauty to understand that above said institutions situated in the USA.

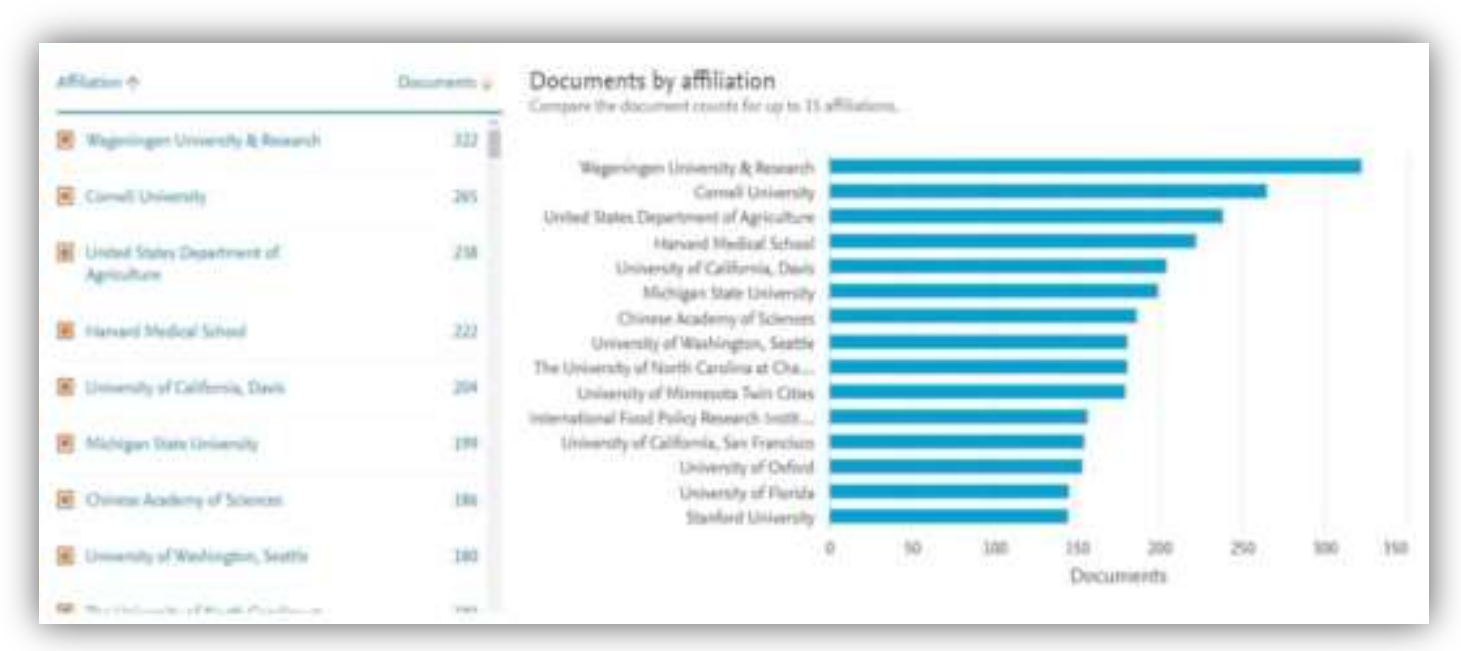

Figure 14.Institutional wise Publication

\section{Finding and Conclusion}

Above findings allow to observe the research behavior activities in the field of Food Economics from 1935 to 2021 as of 15th January. The overall observation in the field is that it could be the basis of the future policy system as well as present highlights and possibility to compare the findings from the heterogeneous situational messages and approaches. As far as publications concerned, it is noteworthy to understand that the reason for the meager output in the beginning stage that it might be either in availability of natural health food or nonavailability of proper media for disseminating their publications.

The current analysis identified the following issues that the interdisciplinary interest in the field of Food Economics over the period, particularly closely related to public health, sustainable agricultural healthy food, framing public policies that deal with directly for food crises [18], [3], [13].

As explained in the introductory part, many people are in the difficult situation to get healthy food as well as right medicine due to global corona virus since 2019.In the current situation, many research organizations is being involved to frame the vaccine for corona virus in which, some countries have found the medicine, but it doesn't sure hundred percentages in recovering from that disease [17]. Therefore, this study feels that it is not easy in recommendation to world reviewers and experts in terms of the current analysis.

However, at this point, another finding in this analysis that the resourcefulness author of Drewnowski, Kesselheim and Popkini where framed their publications inputs that can be considered in making sustainable growth among the public health. In this context, each developing country's government in the world may turn to special attention to the rural places for cultivating and maintaining the agricultural healthy food that is a special suggestion in the current analysis. 


\section{Reference:}

[1] I. N. Sengupta, “ Bibliometrics, Informetrics, Scientometrics and Librametrics: An Overview”, ASLIC Bulletin, vol.42,no.2, (1992),pp.167-174, https://doi.org/10.1515/libr.1992.42.2.75.

[2] G. Seetharam and I. K .Ravichandra Rao, "Growth of food science and technology literature: A comparison of CFTRI,India and the world",Scientometrics,vol.44,no.1,(1999),pp.59-79, https://doi.org/10.1007/bf02458478.

[3] K. Debackere, and W. Glänzel, "Using a bibliometric approach to support research policy making: The case of the FlemishBOF-key",Scientometrics,vol.59,no.2,(2004),pp.253-276, https://doi.org/10.1023/b:scie.0000018532.70146.02.

[4] W. Glänzel, K.Debackere, B. Thijs and A. Schubert, "A concise review on the role of author self-citations in information science, bibliometrics and science polic”,Scientometrics,vol.67,no.2,(2006),pp.263-277, https://doi.org/10.1007/s11192-006-0098-9.

[5] A. Andres, "Measuring Academic Research: How to undertake a bibliometric study", (2009), https://bit.ly/3siqLkn.

[6] J. M. Ramos, G. González-Alcaide, J. Gascón, and F. Gutiérrez, "Mapping of Chagas disease research: analysis of publications in the period between 1940 and 2009”, Revista Da Sociedade Brasileira de Medicina Tropical, vol.4,no.6, (2011),pp.708-716,https://doi.org/10.1590/s0037-86822011005000060.

[7] G. González-Alcaide, J. Park, C. Huamaní, J. Gascón, and J. M. Ramos, “Scientific authorships and collaboration network analysis on Chagas disease: papers indexed in PubMed (1940-2009)”, Revista DoInstituto de Medicina Tropical de São Paulo,vol. 54,no, 4,(2012).

[8] A. Ferrara and S. Salini, "Ten challenges in modeling bibliographic data for bibliometric analysis", Scientometrics, vol.93,no.3, (2012),pp. 765-785, https://doi.org/10.1007/s11192-012-0810-x.

[9] W. Glänzel and P. Woulters, "Selected papers of the Workshop: Combining Bibliometrics and Information Retrieval" held as special event at the 14th International Conference of Scientometrics and Informetrics, Vienna,(2013) July 15, Scientometrics,vol.102,no.3,https://doi.org/10.1007/s11192-015-1532-7.

[10] T. Vanleeuwen, "Letter to the editor publication trends in social psychology Journals: A long-term Bibliometrics Analysis”. European Journal of Social Psychological,vol.11,(2013),pp.9-11.

[11] D. Arnott and G. Pervan, “A Critical Analysis of Decision Support Systems Research Revisited: The Rise of 
Design Science”, Journal of Information Technology, vol.29,no.4,(2014),pp.269-293, https://doi.org/10.1057/jit.2014.16.

[12] J. Mingers and L. Leydesdorff, “A review of theory and practice in scientometrics”, European Journal of Operational Research, vol.246,no.1, (2015), pp. 1-19,https://doi.org/10.1016/j.ejor.2015.04.002

[13] A. Guskov, D. Kosyakov and I. Selivanova, "Scientometric research in Russia: impact of science policy changes”, Scientometrics, vol.107,no.1, (2016),pp. 287-303,https://doi.org/10.1007/s11192-016-1876-7

[14] FAO, “ The State of Food and Agriculture 2019 :Moving forward on food loss and waste reduction. Rome”, Licence: CC BY-NC-SA 3.0, (2019),IGO.http:///www.fao.org/3/ca6030en/ca6030en.pdf.

[15] P. J. García, "Corruption in global health: the open secret”, The Lancet, vol.394,no.10214, (2019), pp.21192124, https://doi.org/10.1016/s0140-6736(19)32527-9.

[16] R. Alders and O. Dar, "2020 Global Hunger Index: One decade to zero hunger linking health and sustainable food systems”,(2020),Reliefweb.https://Bit.Ly/3mSqbJ8. https://bit.ly/3mSqbJ8.

[17] Business Today.In, "Coronavirus vaccine update: List of countries that are closest to finding a treatment". Business Today. (2020),https://Bit.Ly/3diilzG.

[18] K. Nguyen, “ 2020 State of Food Security and Nutrition in the World report: Rising hunger and COVID-19 present formidable challenges", International Food Policy Research Institute (IFPRI), (2020),https://bit.ly/3dlWIUS.

[19] H. Rajput, R. Changotra, P. Rajput, S. Gautam, A. R. K. Gollakota and A.S. Arora, "A shock like no other: coronavirus rattles commodity markets”, Environment, Development and Sustainability, (2020), https://doi.org/10.1007/s10668-020-00934-4.

[20] H. Ritchie, "Environmental impacts of food production",(2020), https://ourworldindata.org/environmentalimpacts-of-food.

[21] R. Sebastiyan, V. Rameshbabu and T. M. Surulinathi, "Mapping of Research Output in Food Economics: A Scientometric Ananlysis”, .Library Philosophy and Practice(ejournal), (2020), https://digitalcommons.unl.edu/libphilprac/4534/.

[22] Johns Hopkins University, "Coronavirus COVID-19: global cases.ArcGIS Dashboards Classic”, (2021),https://Bit.Ly/3skvIcn. 